\title{
DIFFERENTIAL SUPPLY MANAGEMENT BY AGE IN HOTEL TOURISM PRODUCTS
}

\section{ÉLETKOR SZERINTI DIFFERENCIÁLÁS A SZÁLLODAI TURISZTIKAI TERMÉKEKBEN}

\begin{abstract}
Márta Kóródi
Tourism and Catering Department, Business Administration Faculty, John von Neumann University, Hungary
\end{abstract}

\author{
Keywords: \\ hotel management \\ hotel product differentiation \\ segmentation by age \\ product development \\ experience management \\ Kulcsszavak: \\ szállodamenedzsment \\ termékdifferenciálás \\ életkor szerinti szegmentáció \\ termékfejlesztés \\ élménymenedzsment
}

\begin{abstract}
In the development of hotel product strategies, the proportion of diversification and differentiation is a major decision that the hotel offers a wider range of services, which will help to find most suitable for guests, or narrows down its targeted segments and provides them with specific supply elements. One segmentation aspect could be the age of guests. The most prominent and identifiable age group in the supply is the senior, which has always been important for hotels. They have the off-season demand, predictable and well-known needs, their satisfaction is easily accessible. The research is looking for the answer to the question of whether the hotels have the opportunity of acquire the senior segment and what are the special features of the products recommended for them. Parts related to the topic of tourism marketing literature have been reduced to the accommodation services in the secondary information processing section of this paper. This is followed by the identification of the segment's booking and residence habits. Primary analysis of supply will be by observation of collecting and comparing the hotels' offerings to senior guests.

\section{Összefoglalás}

A szállodai termékstratégiák kialakításában a diverzifikálás és a differenciálás közötti arány kialakitása jelentős döntés arról, hogy a szálloda szélesebb szolgáltatáskínálatot nyújt, amiből megtalálja több vendégkör is a számára megfelelöt, vagy leszúkíti a megcélzott szegmenseit és számukra nyújt specifikus kínálati elemeket. Egyik szegmentálási szempont lehet a vendégek kora. A kínálatban leghangsúlyosabban megjelenő és beazonosítható korcsoport a senior korosztály, amely a szállodák számára mindig fontos volt. Szezonon kívül jelentenek keresletet, kiszámíthatóak, ismert igényekkel rendelkeznek, elégedettségük könnyen elérhető. A kutatás arra a kérdésre keres választ, hogy élnek-e a szállodák a senior szegmens megnyerési lehetőségével, valamint milyen sajátosságokat mutatnak a számukra kiajánlott termékek. A tanulmány szekunder információkat feldolgozó részében a turisztikai marketing szakirodalom témához kapcsolódó részei a szállásadásra kerültek leszúkítésre, ezt
\end{abstract}


követi a szegmens jellemző foglalási és tartózkodási szokásainak beazonosítása. A kínálat primer elemzésére megfigyeléssel került sor, a szállodák senior vendégkörnek szánt ajánlatainak összegyüjtésével és összehasonlításával.

\section{Introduction}

In the hotel services market, the product is particular interpreted as range of services that are pre-selected by the guests, or the combination of services that come to an end at the travel completion. The general rules of marketing, phenomena, the conclusions and methods can be used in the accommodation market as well. One topic area is segment-specific product development, which is linked to the relevant marketing mix programs and strategies through the product, e.g. to the market segmentation, consumer habits, i.e. it is a complex marketing management task, in which consumer orientation is well reflected too.

The demands change with age as well, the young tourist has a different experience than the older, experienced traveller one. In terms of tourism demand, five generations appear on the market at the same time and demand is not completely homogeneous within generations. This requires a new type of adaptation and proactivity to maintain market positions for targeting both younger and older generations. Elderly people are characterized by the stereotype of tourists, either passively or restrained, especially those who use medical services, although their consumption structure is more complex and nuanced by their activity growth.

The research of consumer behavior, attitudes by age groups is justified because of their specific communication, so that the influence and dealing with them should be done accordingly. The study collects preliminary knowledge of the characteristics of the most typical segment - senior age group, characterized by tourism affected, which can serve as a suggestion for hotels who choose differentiating product-specific development strategy. The paper is a continuation of a preliminary study of the characteristics of young $(\mathrm{Y}, \mathrm{Z})$ generations [3].

\section{Material and methods}

\subsection{Theoretical background}

Limitation based on ages is determined by the fact that one can be considered a member of the group from the time when new age-related problems arise, such as the loss of health, family-related loss experience and work-related loss experience. At the same time, the distinction "new old" (from retired to the age of seventies) and the "old man" (over seventy) also expresses the differentiation of needs and expectations, but the most deprived picture is the distinction by the children 's independence, retirement, health status and identification of senior status. Self-conscious, critical young elderly people, enlightened, interested young elderly people, and active, flexible young elderly people are the more distinctive aspects of consumer behaviour, which can be considered as a real segment of tourism. At the same time, the experienced senior guest desires new experiences for the enrichment his personality as well [8].

In hotels, it is also necessary to determine which markets and products can display. For this decision, it is necessary to identify the main segments of the market based on different product needs, target market selection and product design, i.e. market targeting. Segment marketing is primarily based on hotel profiling, segments can be further broken down to provide the hotel services to the unsatisfied needs of these small groups, as senior age-group [7].

The selection of the senior market carries the criteria of selective specialization, on the one hand, and product specialization, on the other hand. If the hotel well separates its senior offerings for other guest segments, it specializes in selective specialization. If it offers its existing services to seniors in a specific combination, it is a product specialization. Market segmentation, i.e. full compliance with the diverse needs of the senior segment, and the product innovation are only rarely characterised the latent needs of the segment [2]. In the case of positioning services, the factors that come to the forefront are in line with those preferred characteristics of the senior age group as trust, security, and reliability [6]. 
Some of the expectations of seniors as consumers are not age-specific, but they are natural requirement for the elderly. Such is the love of simplicity, the rejection of unnecessary things, the need for comfort, the appreciation of original, authentic things, and the importance of trust. Evaluated features include naturalness, quality, warmth, friendliness, comfort, softness, non-irritating ingredients, beautiful items, materials, delicate fragrances, flavours, understanding, personalization, and unobtrusive, discreet help [8]. Based on the properties, the senior hotel product can already be outlined. However, for the positioning, further criteria for determining senior tourist travel decisions, such as product features of the service, such as location, aesthetics, symbolic product characteristics, such as demand, economy, cost, consumer group, etc., should be known [5].

\subsection{Multitude and examination}

The exploration of hotel products for senior segment was done by observation. On the basis of the offer of online travel agencies and directly from the hotels website, there are some offers where the product is positioned for the senior segment. The relevant offers of three Hungarian travel portals were fully analysed (www.szallas.hu, www.szallasvadasz.hu, www.utisugo.hu). Cleaned up from duplicates, the database contains 56 offers, complemented by two foreign senior travel portals with offers to compare. In addition to generic offers, at least one product item must be segment specific to have confidence in the age group. The bids were evaluated on a scale of 1-5 based on the number of senior supply items. 1 is the scale value of the supply that only refers to the age group in the name of the package, but there is no special leisure time option for them. This can only mean price differentiation in low demand periods, which is not part of product development. Two is the scale value if there is a special supply item maximum. Scale 3 and 4 mean two or three elements, respectively. If there is more than three, it has a value of five. Among the features, the classification has also appeared, because it can be assumed that in the higher categories, product development is more appropriate for the segments, i.e. the supply is more differentiated.

\section{Results}

Although star rating of hotels is not a mandatory condition for operation at this time, most hotels use the category designation. The hotels offering the examined bids were classified four-star superior, four-star, three-star superior, three-star and two-star, and there were also a number of unrated hotels among the bidders. Being unclassified does not mean a poor quality service; it merely indicates that the hotel did not qualify on the basis of the HotelstarsUnion requirements, which also represents a significant cost to the hotel. The distribution of the sample according to the total multitude of Hungarian hotels is shown in Figure 1, underrepresentation and overrepresentation are also clearly visible.

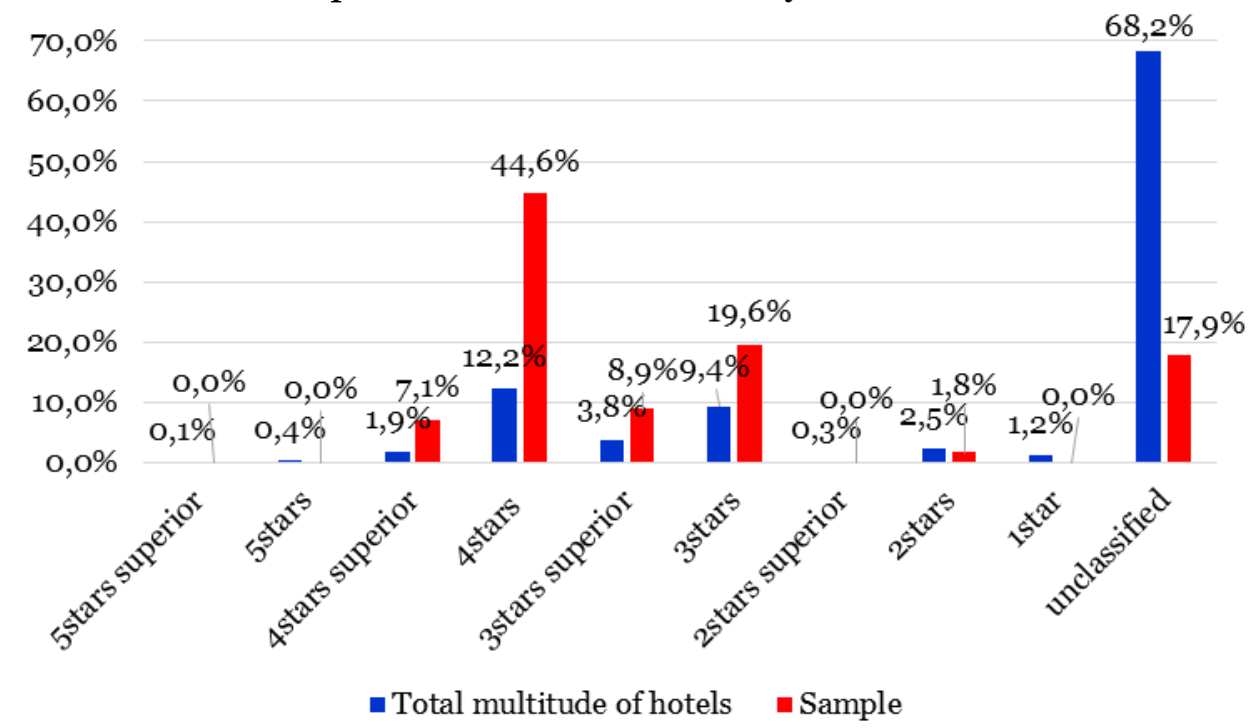


Figure 1 Distribution of database and total multitudes of Hungarian hotels by classification category $(N=1094 ; n=56)$

\section{Source: own editing}

All hotels in the database are rural, presumably the capital city hotels have no charging problems after the season ends, and they do not even make a discount offer, rather than create a segment-specific product. The profiles appearing in the hotels' name are the wellness and the resort, but there are few spa and conference profiles. Spa hotels usually do not offer special services for seniors, as their main segment is this age group, these hotels differentiate according to their duration of stay. The environmental conditions are mixed, the city hotel and the forest hotel were also included in the sample.

Senior packages are named unanimously, with retired and senior terms alternating with package, action, offer, days, and nouns. Gold and silver also appear as an indicative in the names. Several hotels use the popular line of "not only twenty-year-olds have the World" old hits, but they also contain the words of the forever youths, golden-ages, and seniors wellknown call words.

In many cases, the delinquent age is included in the package's fictional name (e.g. "Comfortably over 50"), or a fine reference to the offer called "A decent grey temple". The words „Pensioners” and „Grandparents” are invited to stay with their grandchildren. Two hotels have created a package name „An idyllic retirement weekend”, but one of the best is the "Old Timer Action". The special offer is also announced on behalf of the package by the Öreg-Tó Hotel, named "Electric moped with Tata". The "Senior Experience Package for Health" has been a great success, mainly because of its harmonious content.

The rating of the bids was based on the number of seniors specific supply items, and the frequency of each rating category is shown in Figure 2. It can be stated that the majority of hotels use the price differentiation and give discounts to senior guests in certain periods of lack of demand, but only consider price sensitivity as a segment-specific feature. They do not manage the spare time differently. This strategy is almost half the sample.
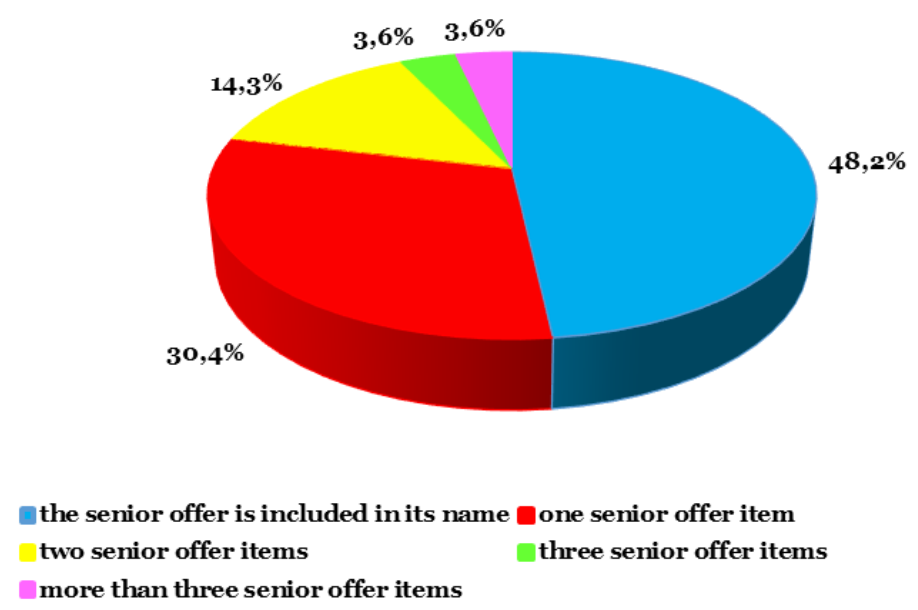

Figure 2. Distribution of database hotels by senior supply $(n=56)$

Source: own editing

The average of the scale values was expected to be around two in the whole sample, as half of the sample was 1 and the other half was at least two, actually 1.84. The hypothesis that the higher category hotels communicate better with the segment's supply can be justified by the breakdown of the average by category (Figure 3). 


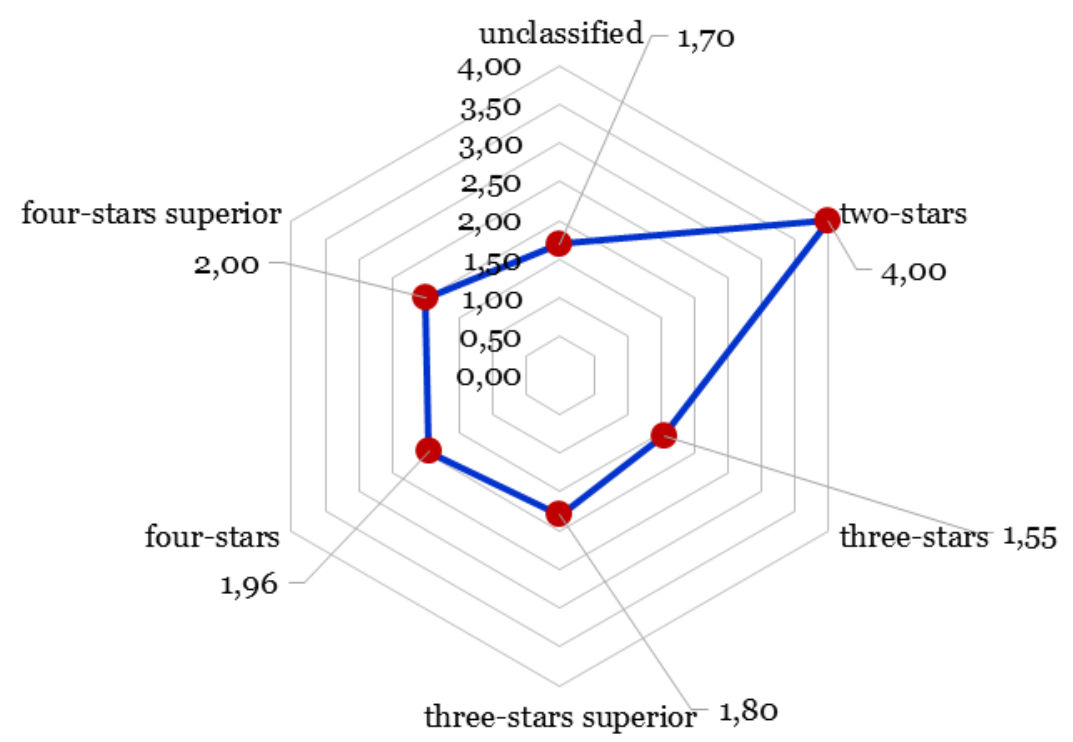

Figure 3 The averages of the prevalence of seniors specific product categories

Source: own editing

The cross-table analysis also shows that the hypothesis has been verified, apart from one occurrence representing the two-star category, in the other categories, a better offer for the segment has been created with improved quality, which is the positive correlation between the rating categorization and the segment-specific product development in the sample.

After a detailed review of the bids, the following elements that occur more than once characterized the senior products:

- $\quad$ They apply to weekdays, more nights on offer, the best arrival for the hotel is on Sunday and the departure on Thursday. There is an extra charge for weekend bookings or extra days (holidays, thematic weekends) or a deal out availability on calendar.

- $\quad$ They offer child discounts, trusting to win grandparents with grandchildren.

- $\quad$ One of the terms of the bids is that it must reserve at least one retired person per room, or one who fulfils the criterion of interest, but one beneficiary can only book one room.

- $\quad$ Optional programs are listed or detailed, but prices are not, or are incomplete, leading to mistrust.

- $\quad$ Half-board is general, but in many cases the guest can choose whether the second main meal outside the breakfast will be lunch or dinner. This is especially beneficial for the elderly to avoid late meals. At the same time, after a generous breakfast, guests are hungry later, than usual, but they cannot stay up until night, so some hotels have introduced soup-lunch.

- $\quad$ The range of complimentary drinks and meals is abundant, once or even daily, with coffee and tea, cake, fruit in room can be included in the package. Afternoon tea is tied up with games (card games, board games) or served in the library, animated as a community program.

- $\quad$ Tastings can be used to train gastronomic openness, e.g. autumn is suitable for honey tasting, but hotel chefs can introduce special ingredients or technology on the dinner buffet table however guests can also find traditional dishes.

- $\quad$ Pets are not an obstacle; tariffs appear next to the package prices.

- $\quad$ The programs adapt to the rhythm of the age group, they are patient on the visit of the manufactory, where the young people can get through quickly. The free museum entrance is also welcomed, the walks in arboretum, lakeside, park, the castle tours, guided city tours, forest tours as well. 
- $\quad$ For physically active seniors cycling (bike rental in the package is free) should be a good spare time program but they must be provided with an itinerary. They are happy to try Nordic walking. Senior gymnastics can be included in the complimentary programs in the outdoor, water or thermal environment. A special senior sports offer to try out the "smovey" vibration ring exercises, which they will mention for their specialty, and will provide a truly enjoyable movement.

- $\quad$ The health condition check is a typical inclusive offer of spa and wellness hotels. During the package travel, the program also includes a massage, but in some places it is replaced by a hydro massage bed. It emphasized the communication of the bath entrants (the same number of guest nights), the bathrobe, towels and other provided accessories.

Adapting services to the different needs of the guests is provided by the system of optional services offerings, e.g. the guests can choose a gratis service from the pedicure, one-hour carriageing or any kind of massage. The guest can also get coupons, which can be limited during a stay (e.g. cosmetic treatment), thus encouraging return. Evening entertainment is accompanied by live music, but can also organize a retro disco.

Foreign hotel senior offers are different from domestic assemblies. Abroad, on the one hand, travel agencies (both traditional and online) traveling with seniors have been set up, managing the entire stay, taking over this role from the hotels. The price advantage is the basis of their communication and they organize complete trips, many of them are luxury round trip or cruises. On the other hand, the wealthier seniors often have an all-inclusive care so that they really do not have to deal with anything but a holiday. It is therefore very difficult to find a senior program in foreign hotels. The BabyBoomerTrips website propose complete allinclusive travels, hotel products, cruises, „bucket list” trips and last minute holydays showing really differentiated offers.

\section{Conclusions}

Hotels strive for even capacity utilization, to compensate for peak and low periods. By maximizing profits during peak periods, and earning as much as possible income that would be to cover the constant cost of maintaining the hotel and the varying costs associated with guest flow and guest consumption during the low periods. Therefore, they are willing and forced to apply reduced prices. A special feature of senior offers is mainly the service supply with discounted price for this price sensitive segment. However, all this is misleading, because the segment - as it is mentioned in the offer - expects special leisure activities from the hotel and faces an indifferent supply (fitness room) and considers itself to be a downgraded segment.

The solution could be the combination of the two strategies, the introduction of at least one senior program that would make the guest feel that the product was developed for him, the hotel cares about it, and at the same time would be no significant additional costs for the hotel. Mostly this can be done with animation and the guests' need to connectivity can be also satisfying. The discounts could still serve as an impulsive for consumption, senior programs would be attractive for a segment wider than a simple discount price, and their experience content would be richer. It could also be an advantage that this psychologically sensitive segment would not feel itself second-rate, obsessed.

It could modulate the solution by developing a higher solvency, more meaningful, longer, multi-optional program for the senior. It would encourage a senior guest to become a frequently guest, if it would be attractive programming elements from the abundant selection besides comfort, which would be worth returning. Being especially friendly, the seniors could be encouraged to return with friends. With a stable senior customer base, the hotel can provide the right capacity utilisation, even in low demanding periods.

\section{Acknowledgement}


This research is supported by EFOP-3.6.1-16-2016-00oo6"The development and enhancement of the research potential at John von Neumann University" project. The Project is supported by the Hungarian Government and co-financed by the European Social Fund.

\section{Bibliographical References}

[1] Baby Boom generáció. Available: http://multkutato.hu/baby-boom-generacio/ [Accessed: 24-11-2018]

[2] Alén, E. -Losada, N. - Carlos, de P. (2017): Profiling the segments of senior tourists throughout motivation and travel characteristics, Current Issues in Tourism, 20:14, 1454-1469, DOI: 10.1080/13683500.2015.1007927 Available:

https://www.tandfonline.com/doi/abs/10.1080/13683500.2015.1007927, [Accessed:24-11- 2018]

[3] Kóródi, M. (2018): Generation management in tourism. In: Pop, Gheorghe; Csata, Andrea; Fejér-Király, Gergely; Kassay, János; Nagy, Benedek; Zsarnóczky, Martin; Pál, László (Ed.) 14th Annual International Conference on Economics and Business. Challenges in the Carpathian Basin. Innovation and technology in the knowledge based economy. Miercurea Ciuc, Románia. Sapientia Hungarian University of Transylvania, pp. 348-357.

[4] Lengyel, M. (2002): A turizmus általános elmélete I. Heller Farkas Gazdasági és Turisztikai Szolgáltatások Főiskolája, Budapest

[5] Lőrincz, K. - Sulyok, J. (Ed.) (2017): Turizmusmarketing. Akadémiai, Budapest Available: https://shibboleth.mersz.org/?xmlazonosito=dj277tm_o_p1\#dj277tm_o_p1, [Accessed: 08-11-2018]

[6] Rekettye, G. - Hetesi, E. (2017): Kínálatmenedzsment. Akadémiai, Budapest Available: https://shibboleth.mersz.org/?xmlazonosito=dj228km_116_p1\#dj228km_116_p1 [Accessed: 1111-2018]

[7] Szigeti, O. - Szakály, Z. (2011): Marketing. Kaposvári Egyetem, Kaposvár Available: https://www.tankonyvtar.hu/hu/tartalom/tamop425/o059_marketing_hu/cho6so2.htm, [Accessed: 08-11-2018]

[8] Törőcsik, M. (2016): Fogyasztói magatartás. Akadémiai, Budapest Available: https://shibboleth.mersz.org/?xmlazonosito=dj72fm_76_p1\#dj72fm_76_p1 [Accessed: 11-112018] 
